\title{
PICROCRYPTOIDES: A NEW GENUS OF THE TRIBE MESOSTENINI FROM SOUTHERN SOUTH AMERICA (HYMENOPTERA, ICHNEUMONIDAE)*
}

\author{
By Charles C. Porter \\ Biological Laboratories, Harvard University
}

The ichneumonid genus Trachysphyrus Haliday and its close relatives within the huge tribe Mesostenini are found in almost every part of the world. With one exception, however, the greatest number of these species seems limited to the Holarctic region. This exception is temperate and subtropical South America.

The ancestors of the present-day South American Trachysphyrus fauna appear to have entered the southern continent from the north. In tropical countries, such as Ecuador and Perú, they radiated only at high altitudes in the Andes (approximately 8,OOO to I4,OOO feet) and, to a lesser extent, in the coastal desert and foothills on the west. None, so far as known, penetrated the tropical cloud-forest and rainforest at lower elevations to the east. In the temperate regions of central and southern Argentina and Chile, on the contrary, this generic group of north-temperate extraction found a more suitable area in which to expand and produced a very complex radiation of close to IOO species, probably more than occur in any area of similar size and, certainly, in greater variety than in any other region which the Trachysphyrus Group inhabits.

Among this Argentine and Chilean radiation are many speciesgroups which depart more or less radically from the customary definition of the genus Trachysphyrus. Some, although superficially bizarre in aspect, are not clearly to be distinguished from the main genus, to which they are often connected by species of intermediate character. Much of the group is still evolving rapidly and generic lines are not always clearly defined. Other series, however, present a combination of unusual features which so isolates them from their relatives that it would seem natural and convenient to place them in separate genera. One such group, the new genus Picrocryptoides, is diagnosed below together with a description of its two known species.

\section{Picrocryptoides, new genus}

Antenna: unusually short and stout: in o subtly enlarged and slightly flattened below toward apex, first flagellomere about 3.2 to 3.8 times

*Manuscript received by the editor April 19, 1965 
as long as wide apically, segments in apical half of flagellum only slightly or not distinctly longer than wide; in $\sigma^{x}$ also unusually stout but considerably tapered toward apex, first flagellomere about 2.4 to 2.6 times as long as wide apically. Ocellar-area: very strongly swollen and prominently raised above level of rest of vertex. Clypeus: strongly assymmetric blunt-pyramidal in profile, the long basal face gently sloping, the short apical face abruptly declivous; apical margin almost truncate to weakly convex on median $2 / 3$, more strongly convex toward sides; corners not reflexed. Malar-space: unusually long, in + about $\mathrm{I} .5$ to $\mathrm{r} .8$ times as long as basal width of mandible, in $\sigma^{\pi}$ about $\mathrm{I} .2$ to $\mathrm{I} .5$ times as long. Fore tibia: not at all inflated. Pronotum: epomia produced above into a broad, conspicuous lappetlike plate. Mesoscutum: notauli reaching about apical $2 / 3$ to $3 / 4$, strong and rather deep throughout or shallower and reduced to a line of large punctures for much of their length. Wing-venation: areolet very large and broad, intercubiti parallel, slightly convergent or a little differentially inclivous above; radial cell unusually short and broad, ending distally at a point distinctly less than half the distance from second intercubitus to tip of wing; nervulus interstitial to somewhat antefurcal; disco-cubitus only slightly angled near middle; ramellus rather long to completely absent; second recurrent a little reclivous on lower $3 / 4$, straightened out or a bit curved or angled above; mediella straight except near base; nervellus broken far below middle, upper part more than twice as long as lower; axillus, over most of its length, a little closer to sub-mediella than to hind-margin of wing. Propodeum: in $q$ rather elongate and gently curved in profile without strong discontinuity between dorsal and apical faces, a little bulging and sphereoid in shape; often with a weak rectangular area-basalis and fine but distinct basal and apical trans-carinae, the latter slightly broadened into low, elongate sublateral cristae, areolation frequently much weaker or entirely absent; in $\sigma^{\pi}$ longer and lower in profile with the areolation only weakly suggested; spiracle long oval. First gastric segment: : : a stout, triangular expansion near base; ventro-lateral carina strong and sharp throughout; dorsolateral carina distinct, sometimes weaker toward base; dorsal carinae

Explanation of Plate 13

Figures 1, 4, and 6. Picrocryptoides hesperios n. sp. male. 1. Dorsal view of head. 4. Propodeal profile. 6. Dorsal outline of postpetiole and apex of petiole. Figures 2, 3, 5, 7, and 8. Picrocryptoides willinki n. sp. 2. Dorsal view of head in male. 3. Propodeal profile of male. 5. Dorsal outline of postpetiole and apex of petiole in male. 7. Anterior view of head of female. 8. Lateral view of apex of ovipositor. Scale: Figures 1 to $7, \times 28$; figure 8 , $\times 52$. 
Psyche, 1965

Vol. 72, Plate 13

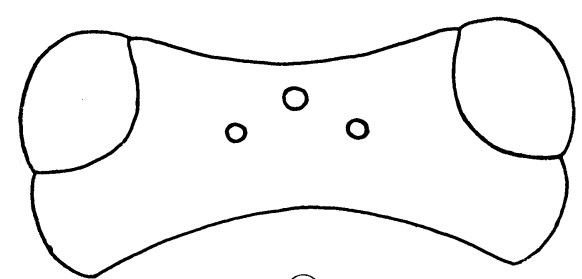

(1)

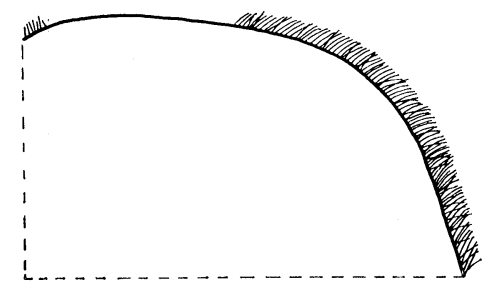

(3)

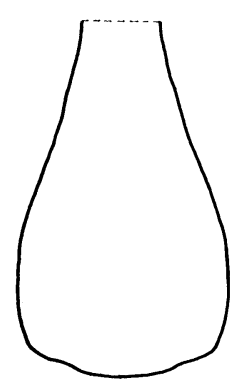

(5)

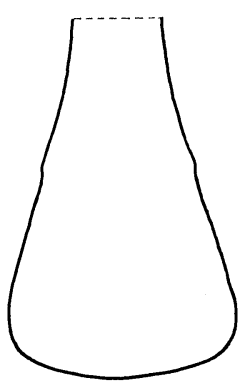

(6)

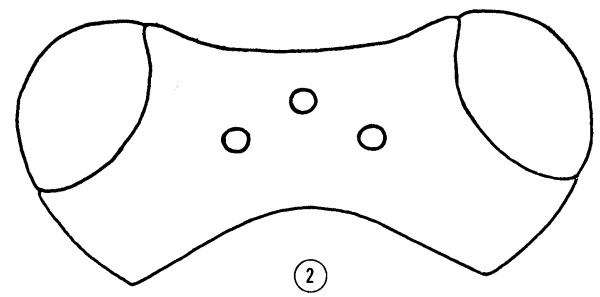

(2)

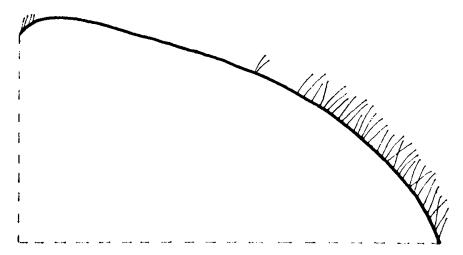

(4)

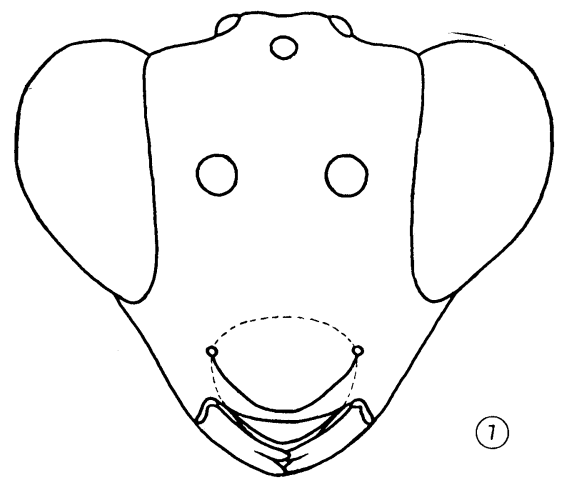

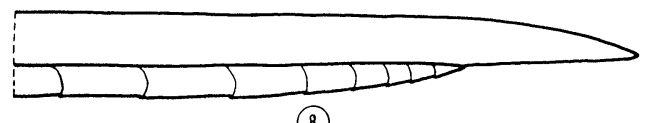

(8)

Porter - Picrocryptoides 
variable, usually traceable but not sharp toward apex of petiole and on base of postpetiole; postpetiole broadly expanded; $\sigma^{\pi}$ : basal expansion as in female or a little blunter; ventro-lateral carina becoming very weak on petiole; dorso-lateral carina not clearly defined; dorsal carinae absent; postpetiole moderately expanded. Second gastric tergite: o: mostly covered with dense, strong adjacent to subadjacent punctures emitting abundant short setae; lateral margin carinate and somewhat reflexed, especially toward base; $\sigma^{x}$ : smooth and shining with many well-separated medium-sized to large more or less superficial punctures emitting long and conspicuous but not extensively overlapping setae. Ovipositor: straight, stout, scarcely compressed; dorsal valve without nodus or notch, straight in profile to near apex, then gently decurved to tip; ventral valve considerably depressed, especially toward apex, its ridges strong and approximately vertical; sheathed portion about 0.28 to 0.30 times as long as fore wing.

TYPE SPECIES: Picrocryptoides willinki n. sp.

Affinities: Picrocryptoides, because of its very large areolet, elongate propodeal spiracle, straight mediella, and the broad postpetiole of the female is a typical member of the Trachysphyrus Group of the tribe Mesostenini. Within this category it is distinguishable from

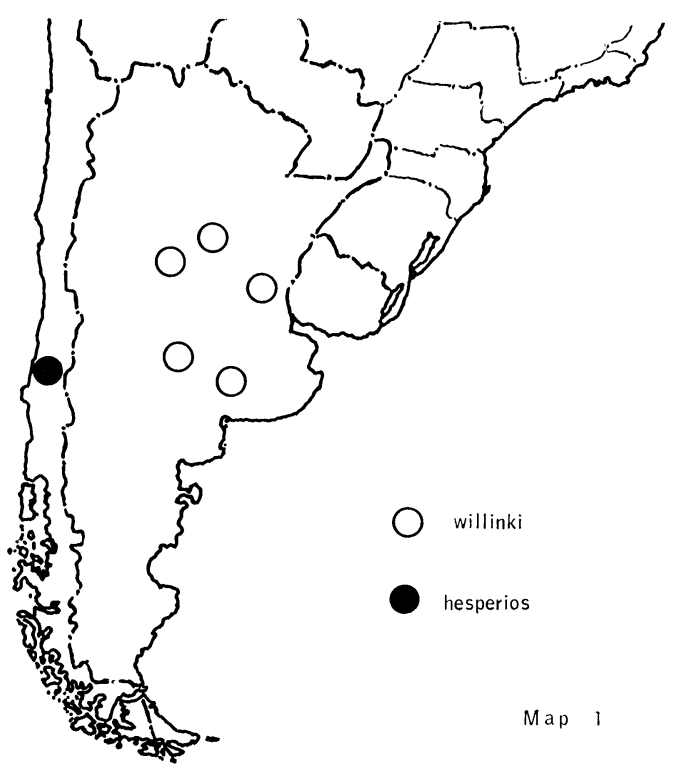

MAP 1. Distribution of Picrocryptoides. 
all other genera most conspicuously by the following combination of characters: the strongly-raised, pyramidal, nose-like clypeus; the inflated ocellar area; the broad, lappet-like dorsal prolongation of the epomia; the unusually short radial cell and the strong basal expansion of the petiole. Other characteristic features, restricted however to the female, are the very long malar space, grossly punctate second gastric tergite, and the short, stout ovipositor without nodus or notch. Various other groups may have one or two of these characters but none approaches having the whole series. Indeed, Picrocryptoides, although obviously a derivative of Trachysphyrus, combines so many distinctive features that it occupies an isolated position within its generic group.

GenerIC NAME: Picrocryptoides is derived from the Greek adjective pikros or sharp and from cryptoides or Cryptus-like, in reference to the pointed clypeus and to Cryptus, a generic name which has commonly been used for many species of the Trachysphyrus Group.

SPECIES: Two species, both new, are available in the material before me. These are described below.

\section{Picrocryptoides willinki n. sp.}

Figures 2, 3, 5, 7, and 8; map I.

TYPES: Holotype: 9 , Córdoba, Argentina, Davis. In Museum of Comparative Zoology, Cambridge, Massachusetts. MCZ. No. 3I I65. Paratypes: ( $4 \sigma^{\pi} \sigma^{\pi}$ and 9oㅇ) from República Argentina (Córdoba: Cosquín, Sierra de Córdoba, March I-9, I920, Cornell University Expedition; Dto. San Martín, January 22, I950, D. Lopez; Yac. Calamuchita, January I 7, I958, A. Willink; Argüello, November I4, 1955, A. Giorgetta; Capital, December 1955, A. Giorgetta; San Luis: San Martín, January 31 to February 3, 1958, Willink and Tomsic; Santa Fe: Rosario, Davis; Buenos Aires: Felipe Sala, January i954, F. H. Walz; La Pampa: Macachia, January I95 I, F. H. Walz); in Museum of Comparative Zoology, Cambridge, Massachusetts; Cornell University Collection, Ithaca, New York; Townes Collection, Ann Arbor, Michigan; Instituto Lillo, Tucumán, República Argentina.

FEMALE: Color: head, thorax, coxae, propodeum, and gaster dull metallic blue-green with scattered obscure purple reflections; antenna dark blackish-brown, becoming somewhat paler toward apex, especially below; apex of mandible brownish-piceous; trochanters shining-black, narrowly brownish apically; fore- and mid-legs bright, pale orange, tarsi brownish or blackish-stained; hind-femur bright pale orange, hind tibia and tarsus moderately dark brown to blackish; wings rather 
dark, with metallic reflections. Length of fore-wing: about 7.3 to $9.0 \mathrm{~mm}$. Temples: smooth and shining with moderately large, shallow subadjacent punctures above, which become much sparser below; setae prominent, considerably longer than the interspaces of the punctures above; strongly, a little roundedly, receding behind eyes, about 0.40 to 0.50 times as long as eye in dorsal view. Occipital carina: rather broad and flange-like above, narrower on temples, especially toward junction with the narrowly flange-like hypostomal carina. Mesopleuron: speculum smooth and shining with a variable number of large, deep punctures; surface otherwise almost uniformly and rather finely and granularly reticulo-punctate, ridges separating punctures a little more broad-crested and shining above, sharper below. Metapleuron: uniformly a little more finely reticulo-punctate than mesopleuron. Propodeum: surface rather finely and granularly reticulo-punctate, often with a patch of much finer granulation medially just back of area-basalis, usually more shining basad of basal trans-carina, where punctures are more widely separated by polished intervals. First gastric segment: postpetiole with strong adjacent to subadjacent punctures laterally and subapically, a narrow apical band smooth and polished and the central area between the dorsal carinae smooth with some scattered large punctures and often with fine longitudinal wrinkling, especially behind.

MALE: Color: much as in female; metallic sheen less strongly greenish, more nearly shining black; antenna blackish, scarcely paler toward apex. Length of fore-wing: about 7.0 to $8.6 \mathrm{~mm}$. Antenna: first flagellomere about 2.2 to 2.6 times as long as wide apically; tyloides linear, on flagellomeres 9 to I7, sometimes last three absent, none of tyloidiferous segments excavated at base. Malar Space: about 1.3 to 1.5 times as long as basal width of mandible. Temples: about 0.50 to 0.60 times as long as eye in dorsal view; strongly receding, a little rounded-off. Meso- and metapleuron: punctures a little more widely spaced than in female, polished interspaces distinct throughout. Propodeum: elongate; dorsal face rather high, gently sloping basally and then more strongly curved to meet the more or less clearly discrete but not sharply differentiated apical face; with strong, dense punctures like those of metapleuron, but about basal $\mathrm{I} / 4$ to $\mathrm{r} / 2$ smooth and shining with only irregularly scattered punctures; laterally, toward apex of dorsal face, and on apical face with long, bushy, erect, dark setae. First gastric segment: postpetiole moderately and gradually expanded, sides, in dorsal view, gently and evenly curved or almost straight in outline from spiracle 
to apex, strongly convex above, smooth and shining with a few widely scattered small, shallow punctures emitting long, conspicuous setae, a few larger punctures grouped above spiracle.

REMARKS: There is considerable variation in the female with regard to development of the propodeal carinae and in the sculpture of the postpetiole. These characters are not themselves correlated nor are they related to other possible distinguishing features. There is thus no basis for recognizing more than one species in the material at hand.

SPECIFIC NAME: This species is named in honor of Dr. Abraham Willink of the Instituto Lillo of the Universidad Nacional de Tucumán, Tucumán, Argentina in thanks for his kind and expert help during my visit to Argentina in November and December of 1964 and in recognition of his valuable series of monographs on the neotropical Hymenoptera.

\section{Picrocryptoides hesperios n. sp.}

Figures I, 4, and 6; map I

TYPeS: Holotype: $0^{*}$, Concepción, Chile, 3/12/1908, P. Herbst. In Museum of Comparative Zoology, Cambridge, Massachusetts. MCZ No. 3i 166 . Paratypes: $\left(20^{\pi} \sigma^{\top}\right)$ : Concepción, Chile, 1903 and Io/r I/1908, P. Herbst. In Museum of Comparative Zoology. MALE: Color: Head, thorax, coxae, propodeum, and gaster dull metallic blue-green, becoming almost black on head and dorsum of thorax; antenna dull blackish-brown; mandible tipped with brownishpiceous; trochanters shining blackish-piceous, narrowly brownish on apices; fore-femur brown, broadly marked with pale testaceous toward apex; hind-femur bright pale orange, a little stained with brown at base and apically above; tibiae and tarsi brownish-black, fore-tibia broadly testaceous below; wings rather dark, with metallic reflections. Length of fore-wing: about 7.4 to $7.6 \mathrm{~mm}$. Antenna: first flagellomere about 2.4 times as long as wide apically; tyloides linear, on flagellomeres 9 to I7. Malar Space: about I.2 to I.3 times as long as basal width of mandible. Temples: rounded-off, scarcely receding, about 0.76 to 0.78 times as long as eye in dorsal view. Propodeum: lower and flatter in profile than in $P$. willinki, dorsal face more steeply sloping and more smoothly merging with apical face; mostly smooth and shining with some large adjacent or subadjacent punctures laterally and on apical $1 / 4$; with prominent long, erect setae, which are conspicuously sparser than in $P$. willinki, laterally and toward apex. First gastric segment: postpetiole moderately expanded, 
sides, in dorsal view, almost straight for more than half the distance from spiracle to apex, then rather abruptly rounded-off; a little less strongly convex above than in $P$. willinki.

REMARKS: This species is intimately related to $P$. willinki but differs especially in the scarcely receding temples and in the much more broadly polished and shining, more sparsely setose, lower and more strongly sloping propodeum. It is possible that future collecting will show that $P$. hesperios is a geographic race of the Argentine species, particularly since there is a wide overlap of the Argentine and Chilean insect faunas from about the latitude of Concepción southward. On the other hand, the distinguishing characters are of a type that generally has specific value in the Trachysphyrus Group so that the most reasonable course at present seems to be the recognition of two distinct species.

SPECIFIC NAME: Hesperios is a Greek adjective meaning western.

\section{RESUMEN}

El autor describe Picrocryptoides, un género nuevo argentino y chileno de la tribu Mesostenini de la familia Ichneumonidae (Hymenoptera). Picrocryptoides es muy parecido a Trachysphyrus Haliday (Cryptus auctorum) pero se diferencia de Trachysphyrus por tener el clípeo elevado en forma de una pirámide asimétrica, la área ocellar elevada y ensanchada, la epomia prolongada hacia arriba en forma de una placa ancha, por tener la celda radial de la ala anterior inusitadamente corta, y por la expansión triangular de la base del pecíolo. Se describen dos especies, ambas nuevas: $P$. willinki de Argentina y $P$. hesperios de Chile. 

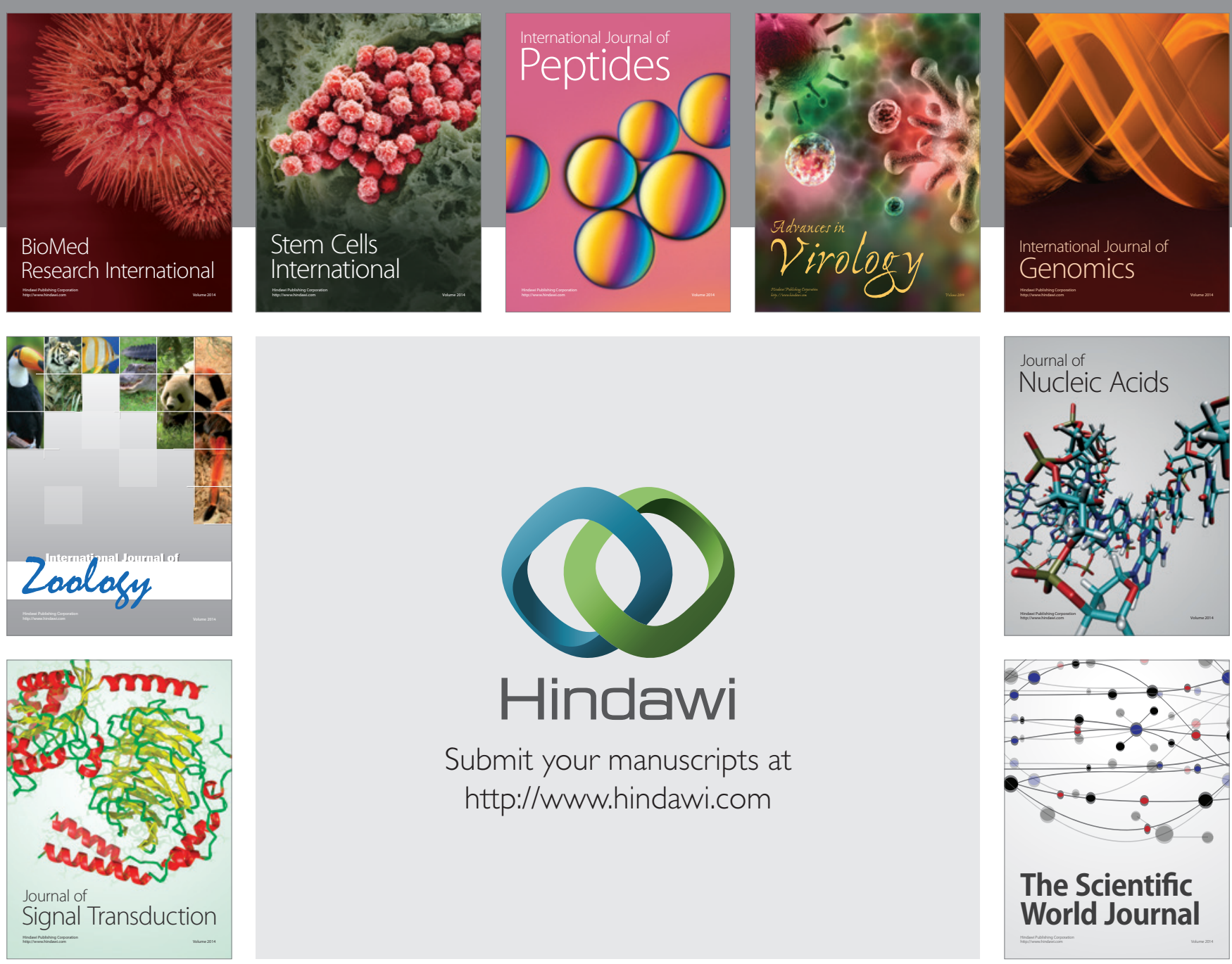

Submit your manuscripts at

http://www.hindawi.com
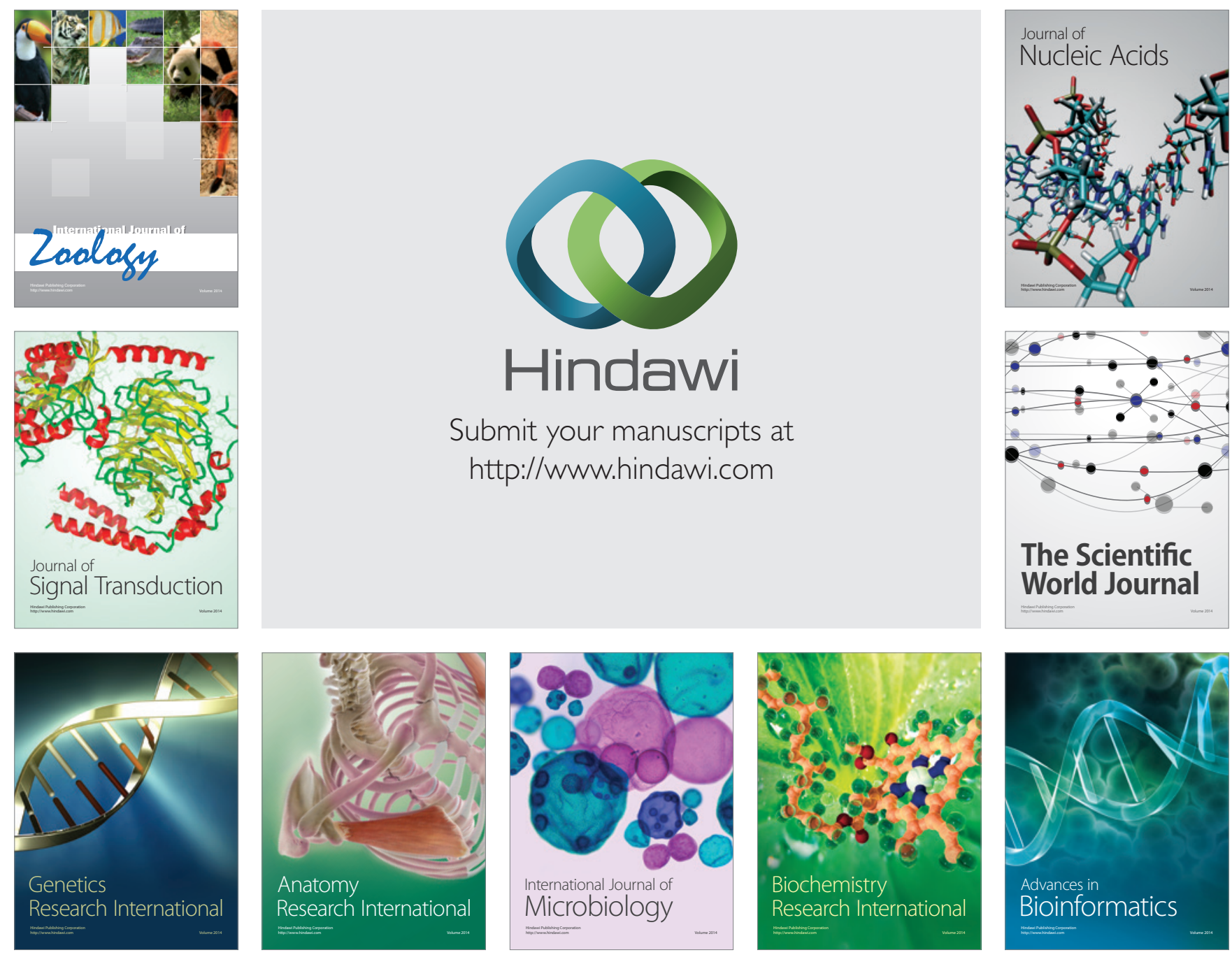

The Scientific World Journal
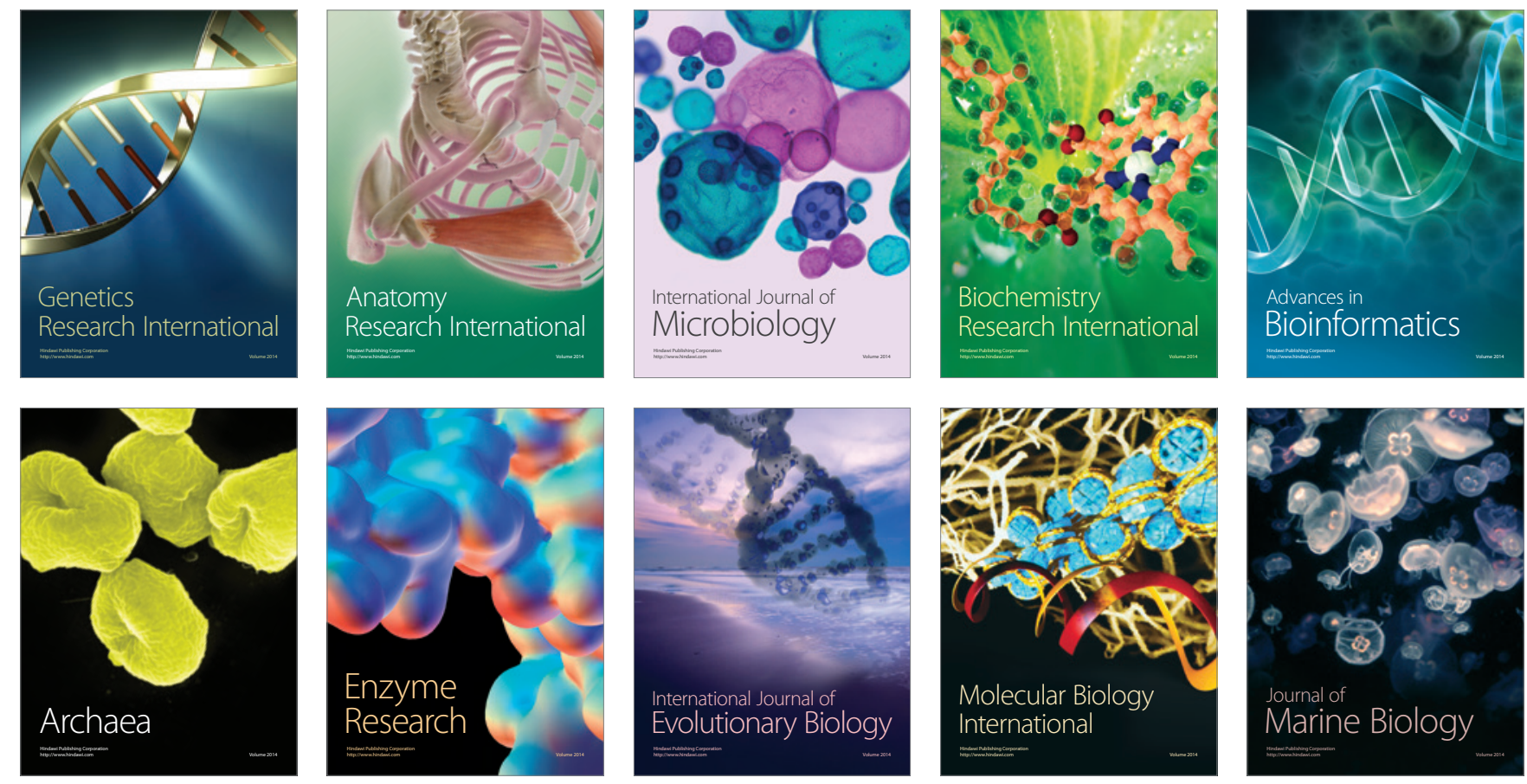